\title{
EDITORIAL
}

\section{The Society of Polymer Science, Japan in the World Polymer Community: The COVER STORY of This New Year's Issue}

Since its foundation in 1951, The Society of Polymer Science, Japan (SPSJ) has actively been contributing to the progress in polymer science and technology, and, as we believe, her continuing contribution has internationally been recognized. With the New Year 2008 commencing, it is increasingly eminent that this field of polymer science and technology is now entering, and so is SPSJ, a new era of progress and perhaps transformation by visibly strengthening its relation with, and impact upon, biology in one hand and physics in the other.

In her wide-spread activities, The Society monthly publishes KOBUNSHI (High Polymers or Macromolecules in Japanese), the official societal organ that provides her currently 12,000 members with valuable information and a forum, with review articles, highlights, commentary, meeting reports, conference programs, among others. Effective of the April 2007 issue, KOBUNSHI underwent a considerable transformation, introducing full-color pages exclusively in English such as the Table of Contents and the brand-new HOT TOPICS section, for strengthening its international contribution and visibility.

Every year KOBUNSHI publishes a special January issue featuring a topic of importance to, hopefully, inspire renewed thoughts and ideas on polymer science and technology among SPSJ members and peers upon the beginning of a New Year. For 2008, the Editorial Board has selected a special topic entitled "The Society of Polymer Science, Japan in the World Polymer Community," and asked international leaders in the field contribute essays or commentaries on:

(a) The future of polymer science and technology;

(b) Their relation with SPSJ;

(c) What they would expect for SPSJ in the coming years as a (hopefully) leading organization in the field.

Ten scientists and editors have kindly accepted our invitation, and the preceding part of this issue complies their contributions (in the order of appearance):

$\begin{aligned} \text { Hiroyuki Nishide } & \text { (Japan; President, The Society of Polymer Science, Japan) } \\ \text { David J. T. Hill } & \text { (Australia; Past President, Pacific Polymer Federation) } \\ \text { Chee-Cheong Ho } & \text { (Malaysia; Chair, Malaysian Polymer Society) } \\ \text { James A. Moore } & \text { (U.S.A.; Chair, Division of Polymer Chemistry, Am. Chem. Soc.) } \\ \text { Christopher K. Ober } & \text { (U.S.A.; President, IUPAC Polymer Division) } \\ \text { Stanislaw Penczek } & \text { (Poland; Titular Member, IUPAC Polymer Division) } \\ \text { Majda Žigon } & \text { (Slovenia; President, European Polymer Federation) } \\ \text { Peter Gölitz } & \text { (Germany; Editor-in-Chief, Angewandte Chemie) } \\ \text { Timothy P. Lodge } & \text { (U.S.A.; Editor-in-Chief, Macromolecules) } \\ \text { David A. Tirrell } & \text { (U.S.A.; Advisory Editor, J. Polym. Chem., Part A: Polym. Chem.) }\end{aligned}$

The KOBUNSHI Editorial Board extends sincere thanks to the authors their positive commitment and does hope that these excellent contributions will inspire thoughts and ideas for the New Year among our members and peers.

Mitsuo Sawamoto

Editor-in-Chief, KOBUNSHI

Vice President, SPSJ 